\title{
Soil attributes and quality under treated domestic sewage irrigation in sugarcane
}

\author{
Eduardo A. A. Barbosa ${ }^{1}$, Edson E. Matsura ${ }^{2}$, Leonardo N. S. dos Santos ${ }^{3}$, \\ Aline A. Nazárioº ${ }^{2}$ Ivo Z. Gonçalves ${ }^{4} \&$ Daniel R. C. Feitosa ${ }^{5}$ \\ ${ }^{1}$ Universidade Estadual de Ponta Grossa/Departamento de Ciência do Solo e Engenharia Agrícola. Ponta Grossa, PR. E-mail: eduardo.agnellos@gmail.com \\ (Corresponding author) \\ ${ }^{2}$ Universidade Estadual de Campinas/Faculdade de Engenharia Agrícola. Campinas, SP. E-mail: eematsura@gmail.com; alineanazario@gmail.com \\ ${ }^{3}$ Instituto Federal Goiano/Campus Rio Verde. Rio Verde, GO. E-mail: leonardo.santos@ifgoiano.edu.br \\ ${ }^{4}$ University of Nebraska/Water for Food Institute. Lincoln, Nebraska, United States of America. E-mail: ivo.zution@gmail.com \\ ${ }^{5}$ Instituto Federal do Sertão de Pernambucano/Campus Floresta. Floresta, PE. E-mail: daniel.feitosa@yahoo.com.br
}

\section{Key words:}

soil functions

water reuse

subsurface drip

fertigation

soil acidification

\begin{abstract}
A B S T R A C T
Using domestic sewage to irrigate and supply nutrients to plants is a sustainable practice; however, due to the physical and chemical properties of the domestic sewage, soil attributes and quality may be changed with its application. The aim of this study was to evaluate soil quality after two cycles of sugarcane irrigated with treated domestic sewage and surface reservoir water via subsurface drip irrigation, with and without nutritional supplementation by fertigation, and a non-irrigated control with top-dressing fertilization. Soil quality was established by applying the methodology proposed by Karlen \& Stott. Physical, chemical and microbiological indicators were selected to compose the basic soil functions used to determine the quality index. Application of treated domestic sewage with fertigation increased soil electrical conductivity, $\mathrm{Na}^{+}$content and exchangeable sodium percentage. Reservoir water applications with fertigation increased microbial biomass carbon and reduced the metabolic quotient, besides promoting significant effects on soil acidification indicators in comparison to reservoir water irrigation without fertigation. Despite the alteration of some soil attributes, no significant changes in the soil quality index were observed among the treatments.
\end{abstract}

Palavras-chave: funções do solo reuso de água gotejamento subsuperficial fertirrigação acidificação do solo

\section{Atributos e qualidade do solo irrigado com esgoto doméstico tratado em cultivo de cana-de-açúcar}

\section{R E S U M O}

O uso de esgoto doméstico para irrigação e suprimento nutricional de plantas é prática sustentável; entretanto, devido às propriedades físico-químicas do esgoto doméstico os atributos e a qualidade do solo podem ser alterados. Assim, o estudo objetivou avaliar os atributos e a qualidade do solo após dois ciclos de cana-de-açúcar irrigada com esgoto doméstico tratado e água de reservatório, com e sem fertigação complementar, e testemunha não irrigada. A qualidade do solo foi estabelecida com a aplicação da metodologia proposta por Karlen \& Stott. Foram selecionados indicadores físicos, químicos e microbiológicos para compor as funções básicas do solo adotadas no índice de qualidade. A aplicação de esgoto doméstico tratado com fertigação elevou a condutividade elétrica do extrato saturado, o teor de $\mathrm{Na}^{+}$e a porcentagem de sódio trocável. O tratamento com água do reservatório e fertigação, elevou o carbono da biomassa microbiana e reduziu o quociente metabólico, além de promover efeitos significativos nos indicadores de acidificação do solo em comparação ao tratamento sem fertigação. Apesar das alterações de alguns atributos do solo, não foi constatado efeitos significativos no índice de qualidade do solo entre os tratamentos. 


\section{INTRODUCTION}

Disposal of treated domestic sewage (TDS) in the soil increases the availability of nutrients, promotes water supply and increases sugarcane yields (Leal et al., 2009; Gonçalves et al., 2017). However, TDS has saline-sodic characteristics that can compromise the agronomic quality of the soil. In this context, increment in $\mathrm{Na}^{+}$and the consequent elevation in exchangeable sodium percentage (ESP) favor the destructuration of the soil, with effect on its aggregated particles through the reduction in weighted mean diameter (WMD), increase in clay dispersion and negative alterations in hydraulic conductivity (Almeida Neto et al., 2009; Paes et al., 2013).

The saline effect of TDS favors the increase in soil electrical conductivity, reduces plants' capacity to absorb water and cause negative impacts on microbiological factors, such as reduction in the stock of carbon $\left(\mathrm{C}_{\mathrm{org}}\right)$, microbial biomass carbon (MBC), metabolic quotient $\left(\mathrm{qCO}_{2}\right)$ and microbial quotient (qMic) (Chowdhury et al., 2011; Setia et al., 2013). It is worth pointing out that, in fertigated systems, there may be problems related to soil salinization and acidification, especially when nitrogen fertilizers are used (Han et al., 2015).

As mentioned, TDS application and nutrient supply method (top-dressing or fertigation) alter soil functioning and quality, which may limit crop development and yield. Among the models used to evaluate soil quality, the one proposed by Karlen \& Stott (1994) stands out, as indicated by Melo Filho et al. (2007) and Fernandes et al. (2011).

In this context, the present study aimed to evaluate soil attributes and quality after two cycles of sugarcane irrigated and not irrigated with treated domestic sewage and reservoir water, with and without supplementary fertigation.

\section{Material AND Methods}

The experiment was conducted in an experimental field. The soil of the area was classified as dystroferric Red Latosol (LVd) (EMBRAPA, 2013) and, before planting, physicalhydraulic characterization was performed in the layers of 0-0.20, 0.20-0.40 and 0.40-0.60 m (Table 1), following the methods proposed by the Agronomic Institute of Campinas (Camargo, 2009). Sugarcane (RB867515) was planted in May
2011; plant cane was harvested in September 2012 and its first ratoon was harvested in August 2013.

The experimental design was randomized blocks, with five treatments and five replicates. Plots were composed of three double planting rows $(1.40 \times 0.40 \mathrm{~m})$, with length of $18.00 \mathrm{~m}$. Treatments were: control, not irrigated with top-dressing fertilization (NI); crop irrigated with TDS and supplementary fertigation (ISF); crop irrigated with TDS without nutritional supplementation (IS); crop irrigated with surface reservoir water (SRW) and supplementary fertigation (IWF); and crop irrigated with SRW without nutritional supplementation (IW).

The amounts of nutrients applied in the treatments NI, ISF and IWF met the recommendations of Rossetto et al. (2008) for high yields, with application of 120, 40 and $60 \mathrm{~kg} \mathrm{ha}^{-1}$ of NPK. Fertilization in NI was applied as top-dressing between the planting rows $(0.40 \mathrm{~m})$, using urea, MAP and potassium sulfate as sources. Fertigation in the treatments ISF and IWF were weekly performed. In ISF, the application of mineral fertilizers complemented the nutrients NPK supplied by the TDS, at proportion of 11, 64 and 54\%, respectively.

For chemical characterization and control of irrigation, TDS and SRW samples were collected after the sand filters of the irrigation system, at a two-month frequency. The methods used followed the protocols described in the Standard Methods for the Examination of Water and Wastewater (APHA, 2012). The obtained mean values are presented in Table 2.

The subsurface drip irrigation system had drippers with flow rate of $1.60 \mathrm{~L} \mathrm{~h}^{-1}$, spaced by $0.65 \mathrm{~m}$ and installed at depth of $0.20 \mathrm{~m}$, between the smallest cultivation row $(0.40 \mathrm{~m})$. Irrigation management was performed using Time Domain Reflectometry (TDR), calibrated for the soil of the area, as recommended by Gonçalves et al. (2017). A TDR 100 (Campbell Scientific) and data acquisition system CR1000 (Campbell Scientific) were used. For irrigation management, TDR probes were installed at depths of $0-0.20 ; 0.20-0.40 ; 0.40$ $0.60 \mathrm{~m}$ and at distance of $0.15 \mathrm{~m}$ in the longitudinal direction.

Soil water balance, calculated by the difference between soil water content (obtained through TDR) and field capacity, was used to establish the irrigation depth. Irrigation depth calculation considered a wetted strip width of $0.50 \mathrm{~m}$, based on the study of Elaiuy et al. (2015).

Soil quality index was established through the model of Karlen \& Stott (1994), Eq. 1.

Table 1. Soil physical attributes of the experimental area

\begin{tabular}{|c|c|c|c|c|c|c|c|c|c|c|c|}
\hline \multirow{3}{*}{$\begin{array}{l}\text { Layer } \\
\text { (m) }\end{array}$} & \multirow{3}{*}{$\begin{array}{l}\text { Soil bulk density } \\
\qquad\left(\mathrm{kg} \mathrm{dm}^{-3}\right)\end{array}$} & \multicolumn{3}{|c|}{ Porosity } & \multicolumn{3}{|c|}{ Texture } & \multicolumn{2}{|c|}{ Moisture } & \multirow{3}{*}{$\begin{array}{l}\text { AWC } \\
(\mathrm{mm})\end{array}$} & \multirow{3}{*}{$\begin{array}{c}K_{s} \\
\left(\mathrm{~cm} \mathrm{~h}^{-1}\right)\end{array}$} \\
\hline & & Total & Macro & Micro & Clay & Silt & Sand & $\theta_{\mathrm{FC}}$ & $\theta_{\text {PWP }}$ & & \\
\hline & & \multicolumn{3}{|c|}{$\left(m^{3} m^{-3}\right)$} & \multicolumn{3}{|c|}{$\left(g_{\mathrm{kg}}^{-1}\right)$} & \multicolumn{2}{|c|}{$\left(m^{3} m^{-3}\right)$} & & \\
\hline $0-0.20$ & 1.28 & 0.54 & 0.13 & 0.41 & 569 & 208 & 223 & 0.36 & 0.25 & 22.0 & 3.29 \\
\hline $0.20-0.40$ & 1.29 & 0.56 & 0.15 & 0.41 & 632 & 158 & 210 & 0.38 & 0.27 & 22.0 & 0.83 \\
\hline $0.40-0.60$ & 1.21 & 0.57 & 0.17 & 0.40 & 647 & 157 & 196 & 0.36 & 0.28 & 16.0 & 2.60 \\
\hline
\end{tabular}

Table 2. Mean values of the chemical attributes of the treated domestic sewage (TDS) and surface reservoir water (SRW), collected along the experimental period

\begin{tabular}{|c|c|c|c|c|c|c|c|c|c|}
\hline \multirow{3}{*}{ Source of water } & \multicolumn{6}{|c|}{ Elements } & \multirow{3}{*}{$\mathrm{pH}$} & \multirow{3}{*}{$\begin{array}{c}\text { SAR } \\
\left(\mathrm{mmol} \mathrm{L}^{-1}\right)^{0,5}\end{array}$} & \multirow{3}{*}{$\begin{array}{c}E C \\
\mu S \mathrm{~cm}^{-1}\end{array}$} \\
\hline & $N^{*}$ & $K$ & $S$ & $\mathrm{Na}$ & COD & $\mathrm{H}_{2} \mathrm{PO}_{4}-\mathrm{P}$ & & & \\
\hline & \multicolumn{6}{|c|}{$\mathrm{mg} \mathrm{L}^{-1}$} & & & \\
\hline TDS & 74.8 & 25.7 & 11.2 & 64.5 & 45.6 & 13.3 & 7.51 & 18.9 & 1091.8 \\
\hline SRW & 0.91 & 1.13 & $<5$ & 2.2 & 23.7 & $<0.1$ & 7.29 & 1.19 & 65.2 \\
\hline
\end{tabular}

* $\mathrm{N}$ - Total nitrogen, $\mathrm{NO}_{3}{ }^{-}<0.3 \mathrm{mg} \mathrm{L} \mathrm{L}^{-1}$, COD - Chemical oxygen demand; SAR - Sodium adsorption ratio; EC - Electrical conductivity 


$$
\mathrm{SQI}=\sum \mathrm{SF}(\mathrm{wt})
$$

where:

SQI - soil quality index;

SF - specific functions of the soil; and,

wt - weight attributed to each function.

Soil specific functions (SF) were selected for the agricultural systems, namely: (a) capacity to not limit root system development (RD); (b) capacity to receive, distribute and provide water to plants $(\mathrm{CW})$; and (c) capacity to receive, provide and cycle nutrients (CN) (Melo Filho et al., 2007; Fernandes et al., 2011). Minimum set of indicators was set based on the degree of association of each indicator with the SFs and weights of the indicators, inside each function (Table 3), and were adapted according to data of Glover et al. (2000), Melo Filho et al. (2007) and Fernandes et al. (2011).

The standardized scoring (SS) used the standardization function proposed by Wymore (1993), normalized in scale from 0 to 1 (Eq. 2). Details on standardization equations and SQI calculation can be found in the studies of Melo Filho et al. (2007) and Fernandes et al. (2011).

$$
\mathrm{SS}=\frac{1}{1+\left(\frac{\mathrm{B}-\mathrm{L}}{\mathrm{x}+\mathrm{L}}\right)^{2 \mathrm{~S}(\mathrm{~B}+\mathrm{X}-2 \mathrm{~L})}}
$$

where:

SS - standardized scoring;

B - critical value or base limit of the indicator, whose standardized score is 0.5 , establishing the limit between poor and good soil quality;

L - initial or lowest value a soil property can express;

$S$ - slope tangent to the curve at the point corresponding to the critical value of the indicator (Eq. 3); and, $\mathrm{x} \quad$ - mean value of the indicator measured in the field.

$$
S=\frac{\log \left(\frac{1}{P P}\right)-1}{\log \left(\frac{B-L}{X-L}\right) \times 2(B+X-2 L)}
$$

After two years of cultivation, soil pits were opened in the central region of the plots and soil was collected in the layers of $0-0.20 ; 0.20-0.40$ and $0.40-0.60 \mathrm{~m}$, and in three points in relation to the drip tape $(0 ; 0.20$ and $0.40 \mathrm{~m})$. The following attributes were analyzed: soil bulk density (BD), total porosity (TP) and macroporosity (MA), potential acidity $(\mathrm{H}+\mathrm{Al})$, electrical conductivity of the saturation extract $\left(\mathrm{EC}_{\mathrm{se}}\right), \mathrm{pH}$, CEC, ESP, organic matter (OM), $\mathrm{MBC}, \mathrm{qCO}_{2}$, qMic and WMD. Resistance to penetration was measured from soil surface using the SoloTrack device (Falker ${ }^{\circledR}$ ), when the average moisture content was $0.348 \mathrm{~m}^{3} \mathrm{~m}^{-3}$. The other soil physical and chemical attributes were determined according to Camargo et al. (2009).

$\mathrm{MBC}$ was established by the fumigation-extraction method and $\mathrm{qCO}_{2}$ determined through the ratio between $\mathrm{MBC}$ and microbial activity, the latter of which was measured by the titration method. The qMic was estimated by the ratio between $\mathrm{MBC}$ and $\mathrm{C}_{\text {org }}$ of the soil.

Soil attributes were subjected to Grubbs' test to verify the occurrence of outliers. After that, soil attributes were subjected to analysis of variance for each layer from 0 to $0.60 \mathrm{~m}$. If the F value in the analysis of variance was significant, Tukey test was applied at 5\% significance level, using the software Sisvar (Ferreira, 2014).

\section{Results AND Discussion}

The standardized scores of soil quality index and soil functions are presented in Table 4. The treatments did not cause

\begin{tabular}{|c|c|c|c|c|c|c|c|c|}
\hline SF & $\begin{array}{c}\text { SF } \\
\text { Weight }\end{array}$ & Ind. & $\begin{array}{c}\text { Ind. } \\
\text { Weight }\end{array}$ & Unit & Lower & $\begin{array}{l}\text { Limits } \\
\text { Upper }\end{array}$ & Optimum & References \\
\hline \multirow{5}{*}{$\mathrm{RD}$} & \multirow{5}{*}{0.3} & $\mathrm{RP}$ & 0.35 & $\mathrm{MPa}$ & & 2 & & Otto et al. (2011) \\
\hline & & BD & 0.25 & $\mathrm{~kg} \mathrm{dm}^{-1}$ & & 1.59 & & Melo Filho et al. (2007) \\
\hline & & MA & 0.20 & $\mathrm{~cm}^{3} \mathrm{~cm}^{-3}$ & & & 0.15 & Melo Filho et al. (2007) \\
\hline & & $\mathrm{pH}$ & 0.10 & - & & & 6.4 & Raij et al. (2001) \\
\hline & & $\mathrm{H}+\mathrm{Al}$ & 0.10 & $\mathrm{cmol}_{\mathrm{c}} \mathrm{dm}^{-3}$ & & 3.8 & & Raij et al. (2001) \\
\hline \multirow{5}{*}{ CW } & \multirow{5}{*}{0.2} & TP & 0.35 & $\mathrm{~cm}^{3} \mathrm{~cm}^{-3}$ & & & 0.514 & Fernandes et al. (2011) \\
\hline & & MA & 0.30 & $\mathrm{~cm}^{3} \mathrm{~cm}^{-3}$ & & & 0.15 & Melo Filho et al. (2007) \\
\hline & & WMD & 0.15 & $\mathrm{~mm}$ & 0.9 & & & Fernandes et al. (2011) \\
\hline & & ESP & 0.10 & $\%$ & & 25 & & Ayers \& Westcot (1994) \\
\hline & & $\mathrm{EC}_{\mathrm{se}}$ & 0.10 & $\mathrm{dS} \mathrm{m}^{-1}$ & 4 & & & Ayers \& Westcot (1994) \\
\hline \multirow{9}{*}{$\mathrm{CN}$} & \multirow{9}{*}{0.5} & $\mathrm{pH}$ & 0.10 & - & & & 6.4 & Raij et al. (2001) \\
\hline & & $\mathrm{H}+\mathrm{Al}$ & 0.10 & $\mathrm{cmol}_{\mathrm{c}} \mathrm{dm}^{-3}$ & & 3.8 & & Raij et al. (2001) \\
\hline & & $\mathrm{EC}_{\mathrm{se}}$ & 0.10 & $\mathrm{dS} \mathrm{m}^{-1}$ & 3 & & & Ayers \& Westcot (1994) \\
\hline & & ESP & 0.10 & $\%$ & & 25 & & Ayers \& Westcot (1994) \\
\hline & & CEC & 0.10 & $\mathrm{cmol}_{\mathrm{c}} \mathrm{dm}^{-3}$ & 4.6 & & & Raij et al. (2001) \\
\hline & & $\mathrm{OM}$ & 0.10 & $\%$ & 1.5 & & & Raij et al. (2001) \\
\hline & & $\mathrm{MBC}$ & 0.15 & $\mu \mathrm{g} \mathrm{C} \mathrm{g}^{-1}$ dry soil & 250 & & & Lopes et al. (2013) \\
\hline & & $\mathrm{qCO}_{2}$ & 0.15 & $\mu \mathrm{gCO}_{2} \mu \mathrm{g}^{-1} \mathrm{C} \mathrm{d}^{-1}$ & 0.2 & & & Kaschuk et al. (2010) \\
\hline & & qMic & 0.10 & $\%$ & & & 2.2 & Jenkinson \& Ladd (1981) \\
\hline
\end{tabular}
alteration in soil quality, and SQI varied from 0.85 to 0.90 .

Table 3. Indicators selected to compose the basic soil functions

SF - Specific soil functions; RD - Capacity to not limit root development; CW - Capacity to receive, distribute, maintain and provide water to plants; CN - Capacity to receive, maintain, provide and cycle nutrients; Ind. - Indicators; RP - Resistance to penetration; BD - Soil bulk density; MA - Macroporosity; H + Al - Potential acidity; TP - Total porosity; WMD - Weighted mean diameter; ESP - Exchangeable sodium percentage; $\mathrm{EC}_{\mathrm{se}}$ - Electrical conductivity in the saturation extract; CEC - Cation exchange capacity; OM - Organic matter; $\mathrm{MBC}$ - Microbial biomass carbon; $\mathrm{qCO}_{2}$ - Metabolic quotient; qMic - Microbial quotient 
Table 4. F test and mean values of standardized scores for soil quality index and soil functions, and of soil attributes for the treatments not irrigated (NI), irrigated with treated domestic sewage with supplementary fertigation (ISF), irrigated with treated domestic sewage without fertigation (IS), irrigated with surface reservoir water and fertigated (IWF) and irrigated with surface reservoir water without fertigation (IW)

\begin{tabular}{|c|c|c|c|c|c|c|c|c|}
\hline Treat./Ind. & Unit & NI & ISF & IS & IWF & IW & F Test & C.V. (\%) \\
\hline SQI & - & 0.86 & 0.85 & 0.86 & 0.85 & 0.90 & $1.93^{\text {ns }}$ & 2.48 \\
\hline $\mathrm{RD}$ & - & $0.77 a b$ & $0.75 b$ & $0.78 a b$ & $0.75 b$ & $0.86 a$ & $2.41^{+}$ & 5.13 \\
\hline CW & - & 0.99 & 0.97 & 0.98 & 0.97 & 1.00 & $0.70^{\text {ns }}$ & 4.36 \\
\hline $\mathrm{CN}$ & - & 0.86 & 0.86 & 0.85 & 0.85 & 0.90 & $0.79^{\text {ns }}$ & 2.66 \\
\hline $\mathrm{BD}$ & $\mathrm{kg} \mathrm{dm}^{-1}$ & 1.26 & 1.28 & 1.25 & 1.25 & 1.21 & $1.35^{\mathrm{ns}}$ & 3.48 \\
\hline TP & $\mathrm{cm}^{3} \mathrm{~cm}^{-3}$ & 0.54 & 0.52 & 0.53 & 0.54 & 0.53 & $0.27^{\mathrm{ns}}$ & 4.74 \\
\hline MA & $\mathrm{cm}^{3} \mathrm{~cm}^{-3}$ & 0.12 & 0.11 & 0.11 & 0.12 & 0.11 & $0.08^{\text {ns }}$ & 33.6 \\
\hline WMD & $\mathrm{Mm}$ & 1.65 & 1.65 & 1.65 & 1.85 & 2.12 & $1.97^{\text {ns }}$ & 18.8 \\
\hline $\mathrm{RP}$ & Mpa & 1.77 & 1.60 & 1.83 & 1.60 & 1.50 & $1.47^{\mathrm{ns}}$ & 11.9 \\
\hline $\mathrm{OM}$ & $\%$ & 3.11 & 3.13 & 2.84 & 3.19 & 2.82 & $1.29^{\text {ns }}$ & 16.25 \\
\hline $\mathrm{EC}_{\mathrm{se}}$ & $\mathrm{dS} \mathrm{m}^{-1}$ & $1.16 a b$ & $1.35 \mathrm{a}$ & $1.00 a b$ & $0.98 a b$ & $0.85 \mathrm{~b}$ & $3.07^{\star}$ & 24.29 \\
\hline $\mathrm{pH}$ & - & $5.61 \mathrm{ab}$ & $5.48 \mathrm{~b}$ & $5.66 \mathrm{ab}$ & $5.49 \mathrm{~b}$ & $5.95 \mathrm{a}$ & $3.87^{\star}$ & 3.02 \\
\hline $\mathrm{Na}$ & $\mathrm{mg} \mathrm{dm}{ }^{-3}$ & $1.54 \mathrm{~b}$ & $5.97 \mathrm{a}$ & $3.29 a b$ & $1.65 \mathrm{~b}$ & $1.50 \mathrm{~b}$ & $7.81^{*}$ & 42.8 \\
\hline CEC & $\mathrm{cmol}_{\mathrm{c}} \mathrm{dm}^{-3}$ & 8.33 & 8.90 & 7.30 & 8.33 & 7.63 & $2.08^{\text {ns }}$ & 16.23 \\
\hline ESP & $\%$ & $0.08 \mathrm{~b}$ & $0.30 \mathrm{a}$ & $0.20 \mathrm{ab}$ & $0.09 b$ & $0.09 b$ & $5.81^{*}$ & 45.1 \\
\hline $\mathrm{Al}+\mathrm{H}$ & $\mathrm{cmol}_{\mathrm{c}} \mathrm{dm}^{-3}$ & $3.75 a b$ & $4.14 \mathrm{a}$ & $2.96 a b$ & $4.08 \mathrm{a}$ & $2.65 b$ & $5.65^{\star}$ & 13.94 \\
\hline $\mathrm{MBC}$ & $\mu \mathrm{g} C \mathrm{~g}^{-1}$ dry soil & $314 a b$ & $361 a b$ & $295 b$ & $415 \mathrm{a}$ & $333 a b$ & $2.38^{+}$ & 27.73 \\
\hline $\mathrm{qCO}_{2}$ & $\mu \mathrm{g} \mathrm{CO}_{2} \mu \mathrm{g}^{-1} \mathrm{C} \mathrm{d}^{-1}$ & $0.031 a b$ & $0.032 a b$ & $0.047 a$ & $0.023 \mathrm{~b}$ & $0.038 a b$ & $2.68^{+}$ & 35.13 \\
\hline qMic & $\%$ & 1.89 & 1.96 & 2.26 & 2.32 & 2.53 & $1.04^{\mathrm{ns}}$ & 20.52 \\
\hline
\end{tabular}

Treat. - Treatments; Ind. - Soil quality indicators; SQI - Soil quality index; RD - Capacity to not limit root development; CW - Capacity to receive, distribute and provide water to plants; CN Capacity to receive, provide and cycle nutrients; RP - Resistance to penetration; BD - Soil bulk density; MA - Macroporosity; H + Al - Potential acidity; TP - Total porosity; WMD - Weighted mean diameter; ESP - Exchangeable sodium percentage; EC $_{\text {se }}$ - Electrical conductivity in the saturation extract; CEC - Cation exchange capacity; OM - Organic matter; MBC - Microbial biomass carbon; $\mathrm{qCO}_{2}$ - Metabolic quotient; qMic - Microbial quotient

Means followed by the same letters in the rows do not differ; *Significant at 0.05 probability level; ${ }^{+}$Significant at 0.1 probability level by Tukey test; ns Not significant

Root development (RD) function showed the lowest values of standardized score and the treatments ISF and IWF were significantly different $(p<0.10)$ from IW (Table 4$)$. The loss of quality relative to this function, in the treatments ISF and IWF, was due to the indicators related to soil acidification $(\mathrm{pH}$ and $\mathrm{H}+\mathrm{Al})$.
Potential acidity was significantly different between the treatments in the $0-0.60 \mathrm{~m}$ profile (Table 4 ) and showed the lowest standardized scores in the fertigated treatments (Figure 1). The treatments ISF and IWF showed higher potential acidity, 4.14 and $4.08 \mathrm{cmol} \mathrm{dm}_{c}^{-3}$, respectively, and differed from IW $\left(2.65 \mathrm{cmol}_{c} \mathrm{dm}^{-3}\right)$. High values of $\mathrm{Al}+\mathrm{H}$ reduce soil
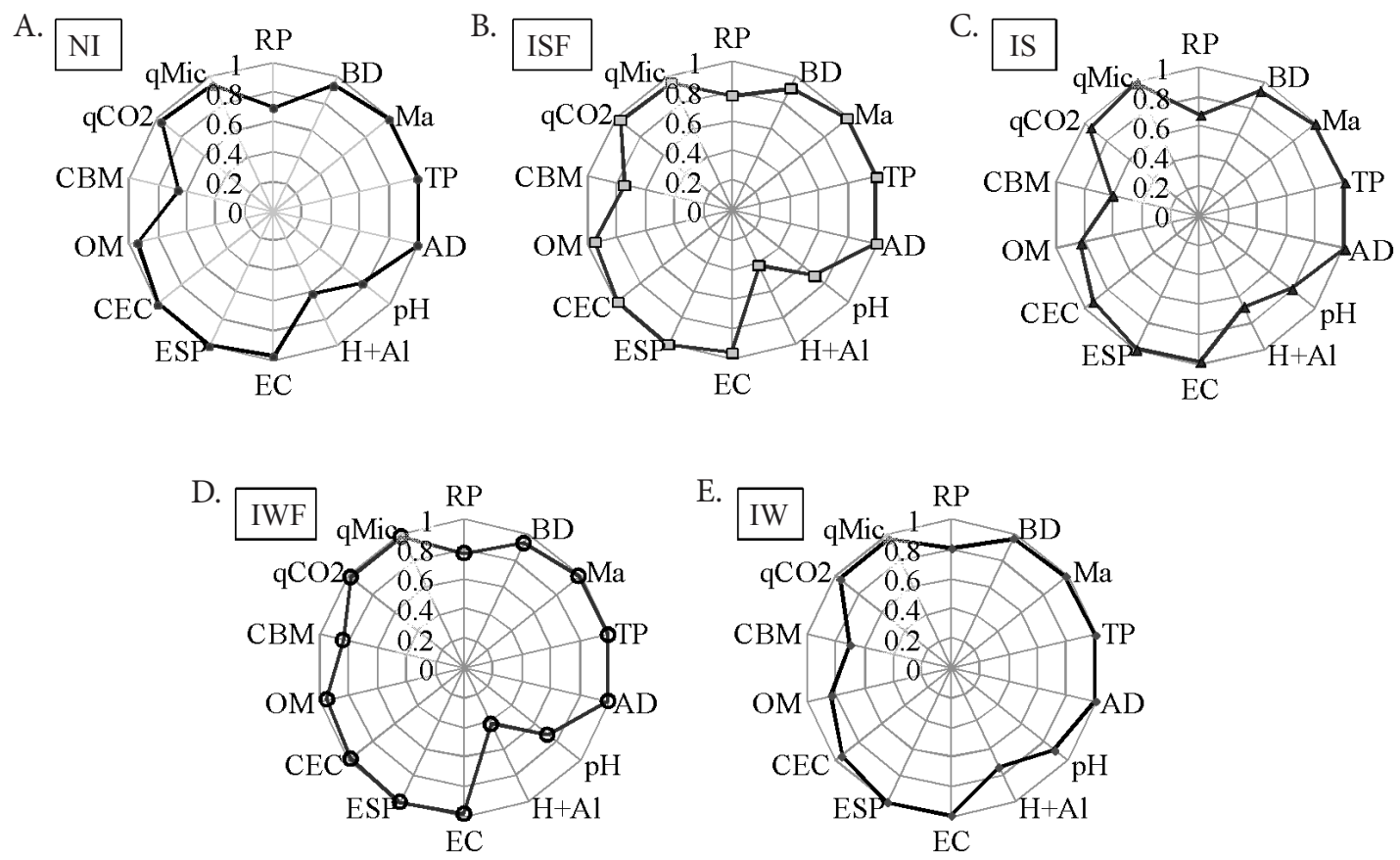

Figure 1. Standardized scores for resistance to penetration (RP), soil bulk density (BD), macroporosity (Ma), potential acidity $(\mathrm{H}+\mathrm{Al})$, total porosity $(\mathrm{TP})$, weighted mean diameter (WMD), exchangeable sodium percentage (ESP), electrical conductivity in the saturation extract (EC), cation exchange capacity (CEC), organic matter (OM), microbial biomass carbon $(\mathrm{MBC})$, metabolic quotient (qCO2) and microbial quotient (qMic) obtained in the treatments (A) not irrigated (NI), (B) irrigated with treated domestic sewage with supplementary fertigation (ISF), (C) irrigated with treated domestic sewage without fertigation (IS), (D) irrigated with surface reservoir water and fertigated (IWF) and (E) irrigated with surface reservoir water without fertigation (IW) 
quality for causing easier exchange of protons between the solid and liquid phases of the soil, which compromises root system development (Haling et al., 2011).

The fertigated treatments (ISF and IWF) obtained the lowest $\mathrm{pH}$ values (5.49 and 5.48, respectively) and differed from IW (5.95) (Table 4). This result suggests possible implications of the application of mineral fertilizers through drip irrigation on soil acidification (Bryla et al., 2010).

The standardized score for RP showed slight reduction, with standardized values close to $0.70-0.80$ (Figure 1); however, according to Table 4, such effect was inherent to the studied soil because there was no significant difference in this indicator between the treatments. It should be pointed out that, at the moment of RP measurement, soil moisture was equal to $0.348 \mathrm{~m}^{3} \mathrm{~m}^{-3}$ and, consequently, it had minimum effect on RP (Molina Júnior et al., 2013).

The adequate values of OM and CEC (Table 4) and high clay contents of the soil (Table 1) led to appropriate values of WMD for the management of agricultural soils, with mean values close to the upper limit $(1.9 \mathrm{~mm})$, presented by Fernandes et al. (2011). The result of WMD indicates an adequate soil particle aggregation and, consequently, resistance to degrading actions, such as presence of $\mathrm{Na}^{+}$applied through TDS, which acts as clay dispersing agent (Šimanský, 2012).

The treatment ISF obtained the highest $\mathrm{Na}^{+}$content $\left(5.97 \mathrm{mg} \mathrm{dm}^{-3}\right)$ and differed from the treatments irrigated with SRW and not irrigated (Table 4), which showed mean values of $1.54,1.65$ and $1.50 \mathrm{mg} \mathrm{dm}^{-3}$, for NI, IWF and IW, respectively. IS obtained intermediate value $\left(3.29 \mathrm{mg} \mathrm{dm}^{-3}\right)$, not differing from the other treatments.

The results of exchangeable sodium percentage (ESP) were similar to those of $\mathrm{Na}^{+}$, and ISF differed from the treatments irrigated with SRW and not irrigated. However, according to the classification of Ayers \& Westcot (1994), the values were low, with small effect on clay dispersion. Thus, the standardized score of this indicator was not reduced (Figure 1). The soil of the experimental area, dystroferric Red Latosol, has good physical characteristics and will hardly be affected by problems related to sodium (Almeida Neto et al., 2009), differently from other soil classes (Paes et al., 2013).

$\mathrm{EC}_{\mathrm{se}}$ values $\left(1.35 \mathrm{dS} \mathrm{m}^{-1}\right)$ in the treatment ISF were higher than those in IW $\left(0.85 \mathrm{dS} \mathrm{m}^{-1}\right)$. The low EC level in IW was due to the absence of mineral fertilizer application and the quality of the applied water (Table 2). The application of fertilizers and TDS in the soil, especially through localized irrigation, has potential to increase soil electrical conductivity (Leal et al., 2009; Han et al., 2015). However, it should be highlighted that ESP and $\mathrm{EC}_{\mathrm{se}}$ did not influence the capacity of the soil to supply water to plants, because these parameters, despite the difference between treatments (Table 4), were within normality, as suggested by Ayers \& Westcot (1994).

The CN function is adequate among the treatments (Table 4). The indicators that most compromise this function were potential acidity, $\mathrm{pH}$ and $\mathrm{MBC}$. In the analysis of $\mathrm{MBC}$, the IWF obtained higher standardized score compared with the others, especially in relation to IS (Figure 1). Statistical analysis evidenced that the treatments did not cause significant differences at $\mathrm{p}<0.05$, but there was effect at $\mathrm{p}<0.10$. At this significance level, MBC values were different between the treatments IWF and IW, which showed mean values of 415 and $295 \mu \mathrm{g} \mathrm{C} \mathrm{g} \mathrm{g}^{-1}$ dry soil, respectively.

The adequate supply of phosphate fertilizer through fertigation favors microbial biomass growth and, consequently, MBC (Lukito et al., 1998). For Franchini et al. (2007), microbiological indicators are highly sensitive to soil use and allow to visualize, in short periods of time, the alterations in soil quality. Thus, the results of $\mathrm{MBC}$ indicate in advance the reduction in the quality of microbiological attributes in the treatment IS.

The standardized scores for $\mathrm{qCO}_{2}$ and $\mathrm{qMic}$ indicate minimum alterations in microbial activity. Significant effects were observed for $\mathrm{qCO}_{2}$ at $\mathrm{p}<0.10$, and IS $\left(0.047 \mu \mathrm{g} \mathrm{CO}_{2} \mu \mathrm{g}^{-1} \mathrm{C} \mathrm{d}^{-1}\right)$ differed from IWF $\left(0.023 \mu \mathrm{g} \mathrm{CO}_{2} \mu \mathrm{g}^{-1} \mathrm{C} \mathrm{d}^{-1}\right)$ (Table 4). The qMic did not differ between treatments and showed values between $1.89 \%(\mathrm{NI})$ and $2.53 \%$ (IW). These values indicate equilibrium between $\mathrm{C}$ accumulation and loss in the soil, which should be close to 2.2\% (Jenkinson \& Ladd, 1981).

After two years of sugarcane cultivation, it was possible to observe modifications in some attributes, especially those related to soil acidification, due to the adoption of fertigation. In addition, $\mathrm{MBC}$ increased in fertigated treatments, especially in IWF.

\section{Conclusions}

1. Joint evaluation of physical, chemical and microbiological indicators allows to claim that, regardless of water quality, SQI was not altered in the first two years of cultivation.

2. Fertigated treatments showed alterations in the indicators related to soil acidification, $\mathrm{H}+\mathrm{Al}$ and $\mathrm{pH}$, which reduced the quality of the function relative to root system development.

3. Irrigation using treated domestic sewage with supplementary fertigation increased the electrical conductivity of the saturation extract, $\mathrm{Na}^{+}$content and exchangeable sodium percentage of the soil.

4. Microbial biomass carbon and microbial quotient were the biological attributes of highest sensitivity to the alterations in the first two years, especially in the treatment irrigated with reservoir water and fertigated.

\section{Literature Cited}

Almeida Neto, O. B. de; Matos, A. T. de ; Abrahão, A. P.; Costa, L. M. da; Duarte, A. Influência da qualidade da água de irrigação na dispersão da argila de Latossolos. Revista Brasileira Ciência do Solo, v.33, p.1571-1581, 2009. https://doi.org/10.1590/S010006832009000600006

APHA - American Public Health Association. Standard methods for the examination of water and wastewater. 22.ed. Washington: APHA/AWWA/WPCF, 2012. 1496p.

Ayers, R. S.; Westcot, D. W. Water quality for agriculture. Rome: FAO, 1994. 177p. Irrigation and Drainage Paper, 29

Bryla, D. R.; Shireman, A. D.; Machado, R. M. A. Effects of method and level of nitrogen fertilizer application on soil $\mathrm{pH}$, electrical conductivity, and availability of ammonium and nitrate in blueberry. Acta Horticulturae, v.868, p.95-101, 2010. https://doi. org/10.17660/ActaHortic.2010.868.8 
Camargo, O. A.; Moniz, A. C.; Jorge, J. A.; Valadares, J. M. A. S. Métodos de análise química, mineralógica e física de solos do Instituto Agronômico de Campinas. Campinas: IAC, 2009. 77p.

Chowdhury, N.; Marschner, P.; Burns, R. G. Soil microbial activity and community composition: Impact of changes in matric and osmotic potential. Soil Biology and Biochemistry, v.43, p.12291236, 2011. https://doi.org/10.1016/j.soilbio.2011.02.012

Elaiuy, M. L. C.; Santos, L. N. S. dos; Sousa, A. C. M. de; Souza, C. F.; Matsura, E. E. Wet bulbs from the subsurface drip irrigation with water supply and treated sewage effluent. Engenharia Agrícola, v.35, p.242-254, 2015. https://doi.org/10.1590/1809-4430-Eng. Agric.v35n2p242-253/2015

EMBRAPA - Empresa Brasileira de Pesquisa Agropecuária. Sistema brasileiro de classificação de solos. Brasília: EMBRAPA, 2013. $353 p$.

Fernandes, J. C.; Gamero, C. A.; Rodrigues, J. G. L.; Mirás-Avalo, J. M. Determination of the quality index of a Paleudult under sunflower culture and different management systems. Soil \& Tillage Research, v.112, p.167-174, 2011. https://doi.org/10.1016/j. still.2011.01.001

Ferreira, D. F. Sisvar: A Guide for its Bootstrap procedures in multiple comparisons. Ciência Agrotecnologia, v.14, p.109-112, 2014. https://doi.org/10.1590/S1413-70542014000200001

Franchini, J. C.; Crispino, C. C.; Souza, R. A.; Torres, E.; Hungria, M. Microbiological parameters as indicators of soil quality under various soil management and crop rotation systems in southern Brazil. Soil \& Tillage Research, v.92, p.18-29, 2007. https://doi. org/10.1016/j.still.2005.12.010

Glover, J. D.; Reganold, J. P.; Andrews, P. K. Systematic method for rating soil quality of conventional, organic, and integrated apple orchards in Washington State. Agriculture, Ecosystems \& Environment, v.80, p.29-45, 2000. https://doi.org/10.1016/S01678809(00)00131-6

Gonçalves, I. Z.; Barbosa, E. A. A.; Santos, L. N. dos S.; Nazário, A. A.; Feitosa, D. R. C.; Tuta, N. F.; Matsura, E. E. Water relations and productivity of sugarcane irrigated with domestic wastewater by subsurface drip. Agricultural Water Management, v.185, p.105115, 2017. https://doi.org/10.1016/j.agwat.2017.01.014

Haling, R. E.; Simpson, R. J.; Culvenor, R. A.; Lambers, H.; Richardson, A. E. Effect of soil acidity, soil strength and macropores on root growth and morphology of perennial grass species differing in acid-soil resistance. Plant Cell Environment, v.34, p.444-456, 2011. https://doi.org/10.1111/j.1365-3040.2010.02254.x

Han, J.; Shi, J.; Zeng, L.; Xu, J.; Wu, L. Effects of nitrogen fertilization on the acidity and salinity of greenhouse soils. Environmental Science and Pollution Research, v.22, p.2976-2986, 2015. https:// doi.org/10.1007/s11356-014-3542-z

Jenkinson, D. S.; Ladd, J. N. Microbial biomass in soil: Measurement and turnover. Soil Biology and Biochemistry, v.13, p.415-417, 1981.

Karlen, D. L.; Stott, D. E. A framework for evaluating physical and chemical indicators of soil quality. In: Doran, J. W.; Coleman, D. C.; Bezdicek, D. F.; Stewart, B. A. (eds.). Defining soil quality for a sustainable environment. Madison: SSSA, 1994. Chap.4, p.53-71.
Kaschuk, G.; Alberton, O.; Hungria, M. Three decades of soil microbial biomass studies in Brazilian ecosystems: Lessons learned about soil quality and indications for improving sustainability. Soil Biology and Biochemistry, v.42, p.1-13, 2010. https://doi. org/10.1016/j.soilbio.2009.08.020

Leal, R. M. P.; Herpin, U.; Fonseca, A. F. da; Firme, L. P.; Montes, C. R.; Melpi, A. J. Sodicity and salinity in a Brazilian Oxisol cultivated with sugarcane irrigated with wastewater. Agricultural Water Management, v.96, p.307-316, 2009. https://doi.org/10.1016/j. agwat.2008.08.009

Lopes, A. A. de C.; Sousa, D. M. G. de; Chaer, G. M.; Reis Júnior, F. B. dos; Goedert, W. J.; Mendes, I. de C. Interpretation of microbial soil indicators as a function of crop yield and organic carbon. Soil Biology and Biochemistry, v.77, p.461-472, 2013.

Lukito, H. P.; Kouno, K.; Ando, T. Phosphorus requirements of microbial biomass in a Regosol and an Andosol. Soil Biology and Biochemistry, v.30, p.865-872, 1998. https://doi.org/10.1016/ S0038-0717(98)00011-X

Melo Filho, J. F. de; Souza, A. L. V.; Souza, L. da S. Determinação do índice de qualidade subsuperficial em um Latossolo Amarelo coeso dos Tabuleiros Costeiros, sob floresta natural. Revista Brasileira de Ciência do Solo, v.31, p.1599-1608, 2007. https:// doi.org/10.1590/S0100-06832007000600036

Molina Júnior, W. F.; Piedade, S. M. S.; Amaral, J. R. Penetration resistance in a Latosol under different moisture and penetration speeds. Revista Ceres, v.60, p.715-721, 2013. https://doi. org/10.1590/S0034-737X2013000500016

Otto, R.; Silva, A. P.; Franco, H. C. J.; Oliveira, E. C. A.; Trivelin, P. C. O. High soil penetration resistance reduces sugarcane root system development. Soil \& Tillage Research, v.117, p.201-210, 2011. https://doi.org/10.1016/j.still.2011.10.005

Paes, J. L. de A.; Ruiz, H. A.; Fernandes, R. B. A.; Freire, M. B. G. dos S.; Barros, M. de F. C.; Rocha, G. C. Dispersão de argilas em solos afetados por sais. Revista Brasileira de Engenharia Agrícola e Ambiental, v.17, p.1135-1142, 2013. https://doi.org/10.1590/ S1415-43662013001100002

Raij, B. van; Andrade, J. C.; Cantarella, H.; Quaggio, J. A. Análise química para avaliação da fertilidade de solos tropicais. Campinas: IAC, 2001. 284p.

Rossetto, R.; Dias, F. L. F.; Vitti, A. C. Problemas nutricionais dos solos nas novas fronteiras canavieiras. Revista Idea News, v.8, p.78-90, 2008.

Setia, R.; Gottschalk, P.; Smith, P.; Marschner, P.; Baldock, J.; Setia, D.; Smith, J. Soil salinity decreases global soil organic carbon stocks. Science Total Environment, v.465, p.267-272, 2013. https://doi. org/10.1016/j.scitotenv.2012.08.028

Šimanský, V. Soil structure stability and distribution of carbon in water-stable aggregates in different tilled and fertilized Haplic luvisol. Acta Universitatis Agriculturae et Silviculturae Mendelianae Brunensis, v.20, p.173-178, 2012.

Wymore, A. W. Model-based system engineering: An introduction to the mathematical theory of discrete systems and to the tricotyledon theory of system design. Boca Raton: CRC Press, 1993. 710p. 